\title{
POLYMORPHISM OF THE CSN2 GENE (VERSIONS A1/A2) IN DIFFERENT BREEDS OF DAIRY CATTLE IN THE CENTRAL BLACK SOIL REGION OF RUSSIA
}

\author{
Eduard A. Snegin ${ }^{*}$, Anton A. Sychev ${ }^{1}$, Olesia Yu. Artemchuk ${ }^{1}$, Anatolii S. Barkhatov ${ }^{1}$, \\ Sergei R. Yusupov', Elena A. Snegina ${ }^{1}$, Aleksandra Yu. Tishchenko ${ }^{1}$ \\ I*Belgorod State University, 85, Pobedy St., Belgorod, 308015, Russia; \\ *Corresponding Author Eduard A. Snegin, e-mail: snegin@bsu.edu.ru;
}

Received August 2021; Accepted September 2021; Published October 2021;

DOI: $\underline{\text { https://doi.org/10.31407/ijees11.438 }}$

\begin{abstract}
USING the method PCR-RFLP, they performed genotyping of cattle for the CSN2 gene (A1/A2 polymorphism). The work studied the cows of six main dairy breeds: Holstein, Simmental, Ayrshire, Brown Swiss, Jersey, Red-andWhite from nine different farms of the Central Black Earth Region of Russia. The gene for beta-casein (CSN2) is located in the chromosome 6 and may be an important marker of milk yield and milk quality. Purpose of the study: to assess the frequencies of the A2 variant and the A2A2 genotype in various breeds of dairy cattle at the breeding farms of the Central Chernozem region of Russia. Materials and Methods: Genomic DNA was isolated from whole blood. 106 b.p DNA fragment was amplified using the primers from the CSN2 gene containing the target mutation. The PCR product was hydrolyzed with the restriction enzyme BstDEI. Gel blocks were stained with ethidium bromide and visualized on UV transilluminator to detect DNA fragments. The samples with the genotype A1A1 had the DNA fragments of 106 b.p., A1A2 - the fragments of 106, 74, 32 b.p., and A2A2 - 74, 32 b.p. Result: The highest frequency of the variant A2 was found in the livestock of the Jersey (0.94) breed, and the lowest in the Simmental breed (0.38). At the same time, there is a significant scatter of A2 frequencies in different cattle of the same breed: in the Holstein breed - from 0.53 to 0.70 , in the Ayrshire breed - from 0.48 to 0.91 . In general, the frequencies of the A2 CSN2 variant in most of the studied breeds take values higher than the average as compared with the data on the same breeds from other regions and countries. In some herds, they revealed a significant deviation of genotype frequencies from the Hardy-Weinberg equilibrium, which indicates the breeding work related to milk quality.
\end{abstract}

Key words: Cattle, CSN2, polymorphism, PCR-ACRS. 